\title{
Effects of sulphur fertilization in organically cultivated faba bean
}

\author{
Zahra Saad Omer ${ }^{1}$, Elisabet Nadeau2,3; Eva Stoltz ${ }^{4}$, Eva Edin ${ }^{5}$ and Ann-Charlotte Wallenhammar ${ }^{4,6}$ \\ ${ }^{1}$ Rural Economy and Agricultural Society, P.O. Box 412, SE-751 60, Uppsala, Sweden \\ ${ }^{2}$ Department of Animal Environment and Health, Swedish University of Agricultural Sciences, \\ P.O. SE-Box 234, 532 23, Skara, Sweden \\ ${ }^{3}$ Rural Economy and Agricultural Society, P.O. Box 5007, 51405 Länghem, Sweden \\ ${ }^{4}$ Rural Economy and Agricultural Society, P.O. Box 271, SE- 701 45, Örebro, Sweden \\ ${ }^{5}$ Rural Economy and Agricultural Society, Brunnby gård 1, SE-725 97, Västerås, Sweden \\ ${ }^{6}$ Department of Crop Production Ecology, Swedish University of Agricultural Sciences, \\ P.O. SE-Box 7043, 750 07, Uppsala, Sweden \\ e-mail: zahra.omer@hushallningssallskapet.se
}

\begin{abstract}
Optimal seed yield and quality requires that the sulphur (S) demand of faba bean (Vicia faba L.) is ensured. The effect of $\mathrm{S}$ fertilization on organic cultivated faba bean was investigated under field conditions during two growing seasons (2017-2018), in Sweden. Kieserite $\left(\mathrm{MgSO}_{4}\right)$ and gypsum ( $\left.\mathrm{CaSO}_{4}\right)$ were applied at a rate of 20 and $40 \mathrm{~kg} \mathrm{ha}^{-1}$ to study the effect on faba bean growth, yield, crude protein (CP) content and amino acid (AA) composition. Gypsum and kieserite significantly increased S concentration of faba bean dry matter (DM) in 2017. The S concentration ranged from $0.20 \%$ to $0.23 \%$ of DM compared to $0.18 \%$ in the untreated control. In 2018 , kieserite application at $40 \mathrm{~kg} \mathrm{ha}^{-1}$ significantly increased S concentration to $0.15 \%$ compared to $0.12 \%$ in the untreated control. The faba bean plants did, however, not respond neither with increased growth nor increased seed yield. The seed quality in terms of CP and S-containing AA, was not affected by S fertilization, however, significant differences were observed between the experimental sites.
\end{abstract}

Key words: Vicia faba L, cysteine, methionine, crude protein

\section{Introduction}

Faba bean (Vicia faba L.) is an important protein crop in organic production and the cultivated area increased from 6000 ha in 2008 to 30000 ha in 2018. As the crop is sensitive to droughts the acreages have since the drought in 2018 decreased to 20000 ha in Sweden. The crude protein (CP) content of faba bean is higher than the CP content of pea (ca $30 \%$ vs. $23 \%$ of DM). Sulphur is one of the essential macronutrients required for normal growth of plants, and often considered as the fourth major nutrient ranking below nitrogen, phosphorous and potassium (Marschner 1995). Insufficient sulphur (S) availability in the soil is reported to affect yield, protein content and amount of S-containing amino acids (Scherer 2009). The reduction of sulphur dioxide $\left(\mathrm{SO}_{2}\right)$ emissions from different industrial sources and the reduction in usage of S-containing pesticides have led to a depletion of $\mathrm{S}$ in the soil (Scherer 2001). A substantial decrease of $80 \%$ in the measured S deposition in Sweden has occurred from 1997 to 2012 (Pihl-Karlsson et al. 2013), which is in line with the reduction of S deposition reported in other European countries (Klein et al. 2011). A sharp decline is shown from 2000-2011, and as a consequence suboptimal levels of $S$ have been recorded in several forage leys in south Sweden by Jonsson (2012). Deposition of S from the atmosphere in Sweden is mainly originating from foreign sources, and there is a clear gradient from $<1 \mathrm{~kg} \mathrm{ha}^{-1}$ in the soil in the central part of Sweden to the highest concentrations in the south-west of Sweden, corresponding to $>4 \mathrm{~kg} \mathrm{ha}^{-1}$ in soil water (Phil-Karlsson et al. 2013). Sulphur deficiencies in sulphur-demanding crops, especially oil seed rape, wheat and grass leys, became apparent in the early 1990s in Sweden (Andersson 1996) and, consequently, $\mathrm{S}$ was added in selected mineral fertilizers.

The consequences of S deficiency can become economically important for growers by reduced yield and impaired seed quality (Głowacka et al. 2019). The demand for fertilizers containing sulphur and proper recommendations to growers have, therefore, increased. In addition to its direct role in seed production and seed quality, lack of S influences other macronutrients, for example nitrogen, through inhibition of nitrogen fixation in legumes, which eventually reduces plant growth (Cazzato et al. 2012). However, the reduced nitrogen fixation may be expressed as small and few nodules on the roots. Atmospheric nitrogen fixation plays a major role in the protein synthesis of the crop, especially as faba bean synthesizes $62-74 \%$ of its nitrogen through biological nitrogen-fixation (Amanuel et al. 2000). 
The effect of S fertilization in yield and seed quality of faba beans has been investigated in other studies (Pötzsch et al. 2018). As a result, the legume proportion in mixed grass-legume leys decreases when the legumes suffer from S deficiency (Tallec et al. 2008a, Tallec et al. 2008b).

On farms with animal production, a large part of the nutrient supply consists of farmyard manure (FYM) containing small amounts of organically bound sulphur, which is largely inaccessible for the plant (Pedersen et al. 1998). It is very difficult to assess the importance of sulphur supplied by liquid FYM and it is considered to be of very little importance according to Eriksen and Mortensen (1999). Studies in Sweden have shown that liquid FYM contains lower levels of S ranging from 0.3 to $0.6 \mathrm{~kg} \mathrm{ha}^{-1}$ (Jonsson 2012), compared to the guidelines specified by the Swedish Board of Agriculture (Jordbruksverket 2019). On the other hand, FYM was found to improve S mineralization in the soil (Boye et al. 2009). Other organic fertilizers, such as bone meal and meat bone flour, contain relatively small amounts of organically bound $\mathrm{S}$, which is difficult for plant to absorb. Improved protein yield and digestibility of faba beans due to sulphur addition was reported by Cazzato et al. (2012). The presence of S-containing amino acids (cysteine and methionine) can potentially increase with increased S-uptake in faba bean and thus cause an altered amino acid composition (Josefsson 1970, Eppendorfer and Eggum 1996).

The aim of this study was to investigate the effect of S fertilizer applications in organically cultivated faba bean with focus on growth, yield, and contents of protein and S-containing amino acids. The overall objective is to produce recommendations for sulphur supply in organic faba bean production. We hypothesized that S application in faba bean results in; 1 ) increased growth and yield, 2) higher protein content and a modified amino acid composition.

\section{Materials and methods Experimental design of field trials}

Faba bean field experiments were established in field crops of faba beans in four counties in Sweden in 2017 (-17) and 2018 (-18): Östergötland (ÖS), Skåne (SK), Västra Götaland (VG) and Örebro (ÖR), using different locations within each county between the years (Table 1). The pre-crops were as follows: ÖS-17 (spring barley); SK-17 (winter wheat); VG-17 (winter wheat); ÖR-17 (oats); ÖS-18 (winter wheat); SK-18 (spring barley); VG-18 (oats); ÖR-18 (spring barley). Weed control was performed by harrowing twice in SK-17 and SK-18 but not in the other fields.

Table 1. Location of the field experiments, date for sowing and harvest, precipitation and temperature at sowing and harvest

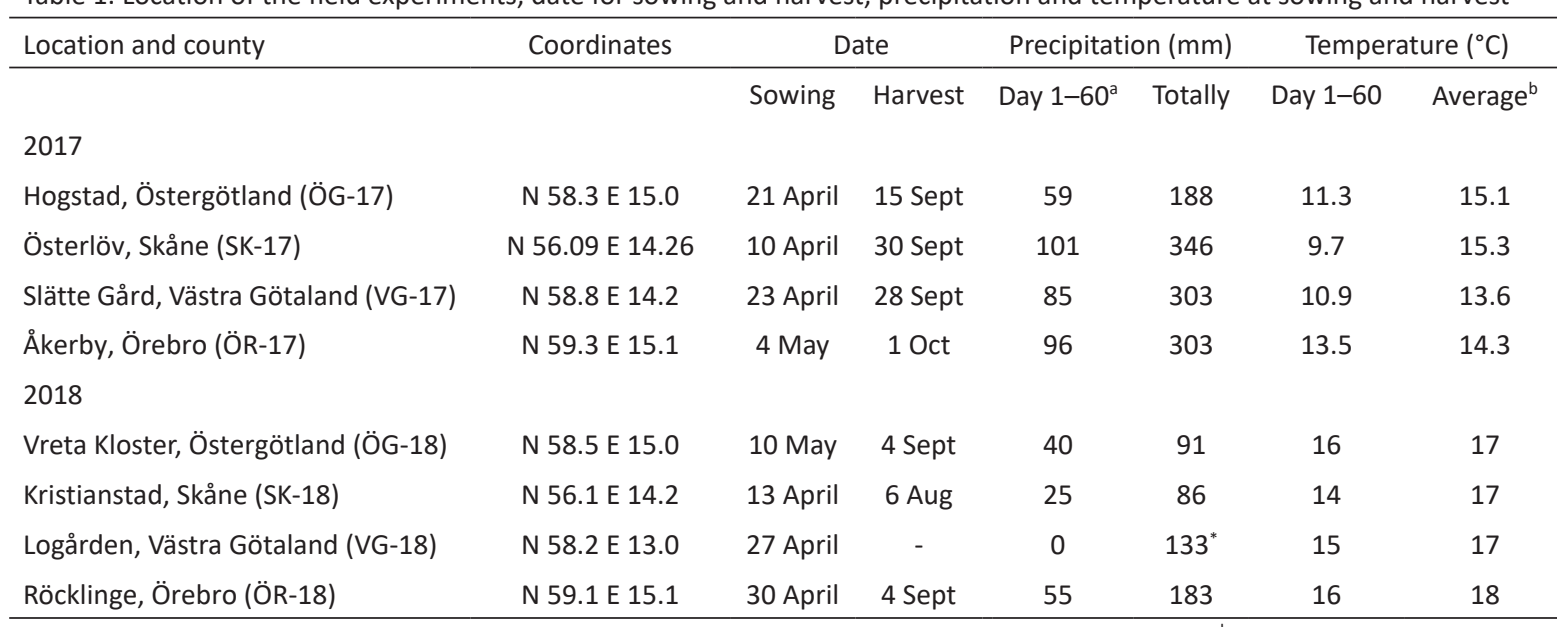

${ }^{\mathrm{a}}=$ precipitation from sowing date to the day when the plants were cut by hand for amino acids analysis; ${ }^{\mathrm{b}}=$ average temperature over the whole growing period

Each field experiment was designed as a randomized block with four replications, each with a plot size of $12 \mathrm{~m} \times$ $3 \mathrm{~m}$. Sulphur was broadcasted and incorporated into the soil by a harrow as kieserite $\left(\mathrm{MgSO}_{4}\right)$ or gypsum $\left(\mathrm{CaSO}_{4}\right)$, each at application rates of $20 \mathrm{~kg} \mathrm{Sha}^{-1}$ and $40 \mathrm{~kg} \mathrm{~S} \mathrm{ha}^{-1}$ before sowing, which were compared to an untreated control. Faba bean was sown at $12.5 \mathrm{~cm}$ row spacing at a density of 60 germinated seeds $\mathrm{m}^{-2}$ with a seeder (Winterstieger combi seeder). The cultivar Julia (Ssd) was used in the field experiments in 2017 and the cultivar Tiffany (Ssd) was used in 2018. Soil samples were collected, before sowing, from a depth of 0-30 cm, 30-60 cm and 60$90 \mathrm{~cm}$, respectively with a soil auger $(20 \mathrm{~mm}$ diameter). Soil chemical properties were analysed at Eurofins Food \& Agro Testing AB, Kristianstad, Sweden (Table 2), as follows: soil pH determined according to (SS (Swedish standard)-ISO 10390), P-AL, K-AL (SS 028310/SS 028310T1), sulphur (Blair et al. 1991), organic matter (KLK1965:1), soil texture (SS ISO 11277 mod.) and mineral N (ADAS method 53). 


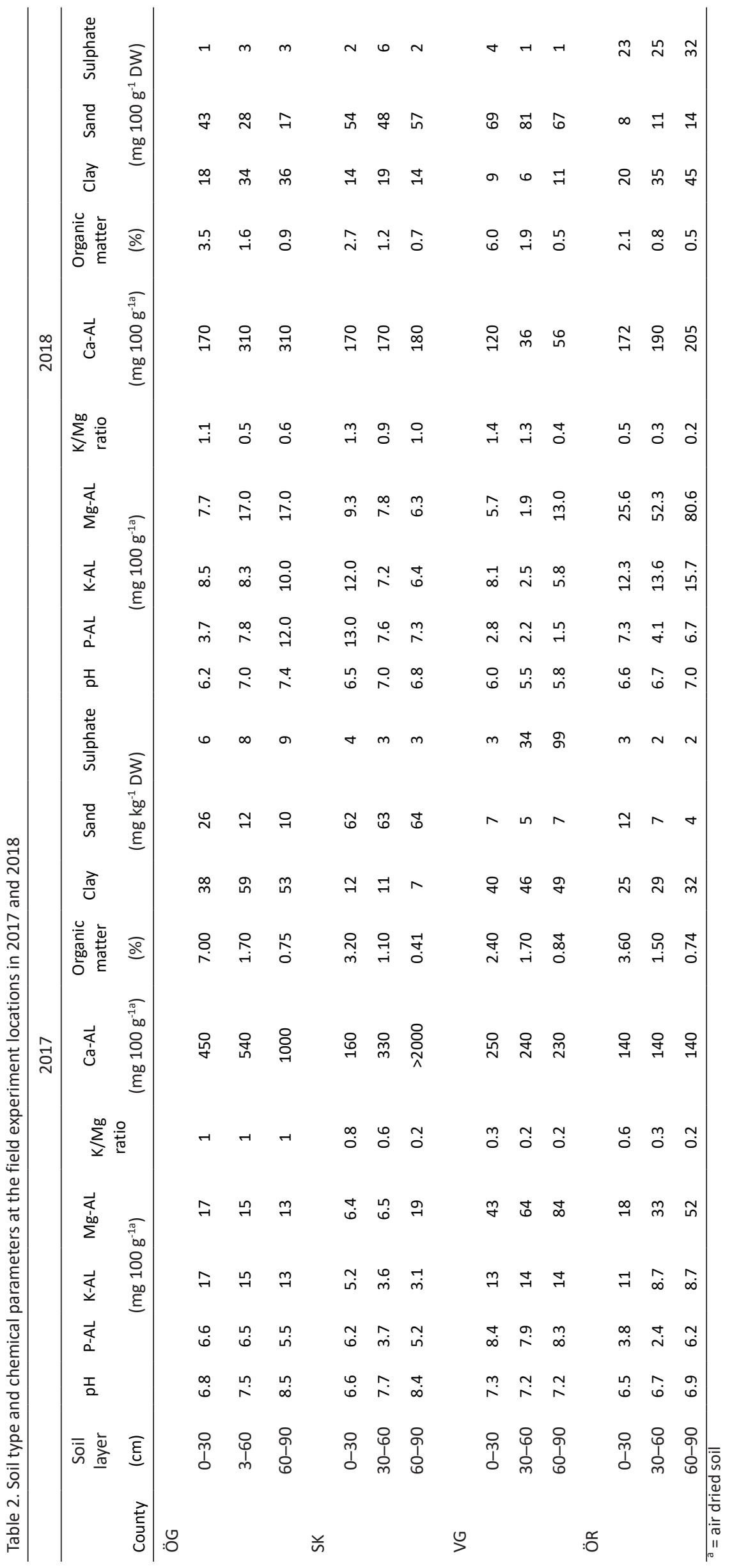




\section{AGRICULTURAL AND FOOD SCIENCE}

\section{Parameters investigated in field experiments}

\section{Registrations of crop canopy and analysis of nitrogen uptake and plant nutrient content}

A visual rating of the crop canopy was performed on a scale of $0-100 \%$ at $\mathrm{BBCH} 60$, to assess plant density. In addition, at BBCH 60 (Weber and Bleiholder 1990), at early flowering, faba bean shoots were harvested by hand by cutting two areas of $0.5 \mathrm{~m}^{2}$ in each plot and both fresh and dry weights of plant biomass were recorded. Samples were dried in a forced-draught oven at $70{ }^{\circ} \mathrm{C}$ for $24 \mathrm{~h}$ and corrected for residual water content, by drying a subsample for $2 \mathrm{~h}$ at $105^{\circ} \mathrm{C}$ for DM determination. Dry weight of whole-plant faba bean was not determined in field experiment SK-17. Plant macro- and micronutrients were analysed at Yara Megalab ${ }^{\text {TM }}$, Yara UK Limited, Pocklington, UK, according to Bergmann (1992).

The nitrogen uptake was estimated with an N-sensor (Yara) at BBCH 60 in six out of the eight field experiments. Corresponding measurements were performed with Green Seeker handheld Crop Sensor (Trimble Agriculture, Westminster, Colorado 80021, USA) at the two remaining field experiments, field SK-17 and SK-18. The Green Seeker measures the crop's reflectance of light and from that it is possible to calculate the N content using complex agronomic calculations called NDVI.

Registrations of seed yield and analysis of crude protein and amino acids

The faba bean was harvested at maturity ( $\mathrm{BBCH} 88-89$ ), weighed and water content was determined. At harvest, undried bean samples were collected to determine CP content as well as the contents of the amino acids lysine, methionine, cysteine, threonine, valine and histidine. Total $\mathrm{N}$ was analysed by the Kjeldahl method and the CP was calculated as total $\mathrm{N} \times 6.25$. The analyses were performed at LKS mbH, Lichtenenwalde, Germany. At the field experiment VG-18, only bean samples were taken from each plot and analysed for CP and amino acid contents due to poor plant growth caused by drought and high occurrence of weeds.

\section{Statistics}

The results were analysed by year using a mixed linear model with treatment, location and the interaction between treatment and location as fixed factors and block (location) as a random factor in JMP statistical software (ver.9.0) (USA) and SAS (ver. 9.3) (SAS Inst. Inc. Cary, NC). Four blocks were used per location and year. If the F-value for the main effect of treatment and location and the interaction effect between treatment and location was significant $(p<0.05)$, pairwise comparisons were performed using Tukey's HSD test to identify differences between individual means. The biomass weights in the beginning of flowering were transformed by logarithm to reduce the variance. Contrast analyses were performed, i.e. the untreated control was compared with the mean of all sulphur treatments.

\section{Results}

\section{Crop canopy density and nitrogen uptake}

The visual assessment of the crop density (\% coverage of ground) at BBCH 60 showed in field experiment VG-17 that the crop density of the untreated control was significantly lower (80\%) compared to the treatment with $20 \mathrm{~kg}$

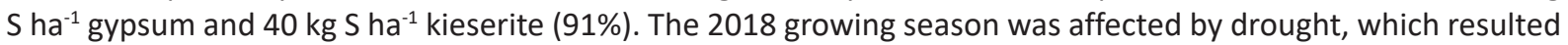
in low faba bean growth in comparison to the 2017 field experiments. The results of $\mathrm{N}$ uptake by measurements with Yara's N-sensor and Green Seeker, showed no significant differences between the treatments (not shown).

\section{Biomass}

The weight of plant dry mass (DM) at early flowering in 2017, was highest in ÖG- followed by ÖR and was lowest in VG, whereas the plant DM in 2018 was highest in SK-18, intermediate in ÖG and ÖR and lowest in VG $(p<0.001$; Table 3). There were no differences in biomass DM yield between the S fertilization treatments.

\section{Plant sulphur concentration and $\mathrm{N}: \mathrm{S}$ ratio}

The application of gypsum or kieserite significantly increased the average $S$ concentration of the dry biomass compared to the control at early flowering stage in field experiments conducted in 2017 ( $p<0.001$; Table 3). No significant additional increase was obtained by the application of $40 \mathrm{~kg} \mathrm{~S} \mathrm{ha}^{-1}$. In 2018, application of 
$40 \mathrm{~kg} \mathrm{~S} \mathrm{ha}^{-1}$ kieserite to the soil significantly increased the S concentration in faba bean DM compared to the untreated control $(p<0.001)$. The S concentration was higher in ÖR than in all the other locations in both years $(p<$ 0.001; Table 3). There were no interactions between treatments and locations (results not shown).

The S uptake by the crop at early flowering ranged from 2.4 to $18 \mathrm{~kg} \mathrm{~S} \mathrm{ha}^{-1}$ in 2017 and from 2.3 to $4.3 \mathrm{~kg} \mathrm{~S} \mathrm{ha}^{-1}$ in 2018 among locations ( $p<0.001$; Table 3). The S treatments did not affect the $\mathrm{S}$ uptake in 2017, whereas addition of $40 \mathrm{~kg} \mathrm{~S} \mathrm{ha}^{-1}$ of kieserite in 2018 increased $\mathrm{S}$ uptake in the faba bean compared to the untreated control $(p<0.05 ;$ Table 3).

The ratio of nitrogen to sulphur content (N:S) in faba bean at early flowering differed between locations in both years (Table 3). The ÖG and VG locations had higher N:S ratios than the SK and ÖR locations in 2017, which did not differ. In 2018, the ÖG location had the highest N:S ratio, followed by SK, which had a higher ratio than VG and ÖR $(p<0.001)$. The $\mathrm{S}$ treatments did not significantly affect the $\mathrm{N}: \mathrm{S}$ ratios (Table 3).

Table 3. Biomass dry matter, sulphur concentration, sulphur uptake, $\mathrm{N}: \mathrm{S}$ ratio of faba bean at early flowering (BBCH 60 ) at the eight field locations in 2017 and 2018 with sulphur treatments

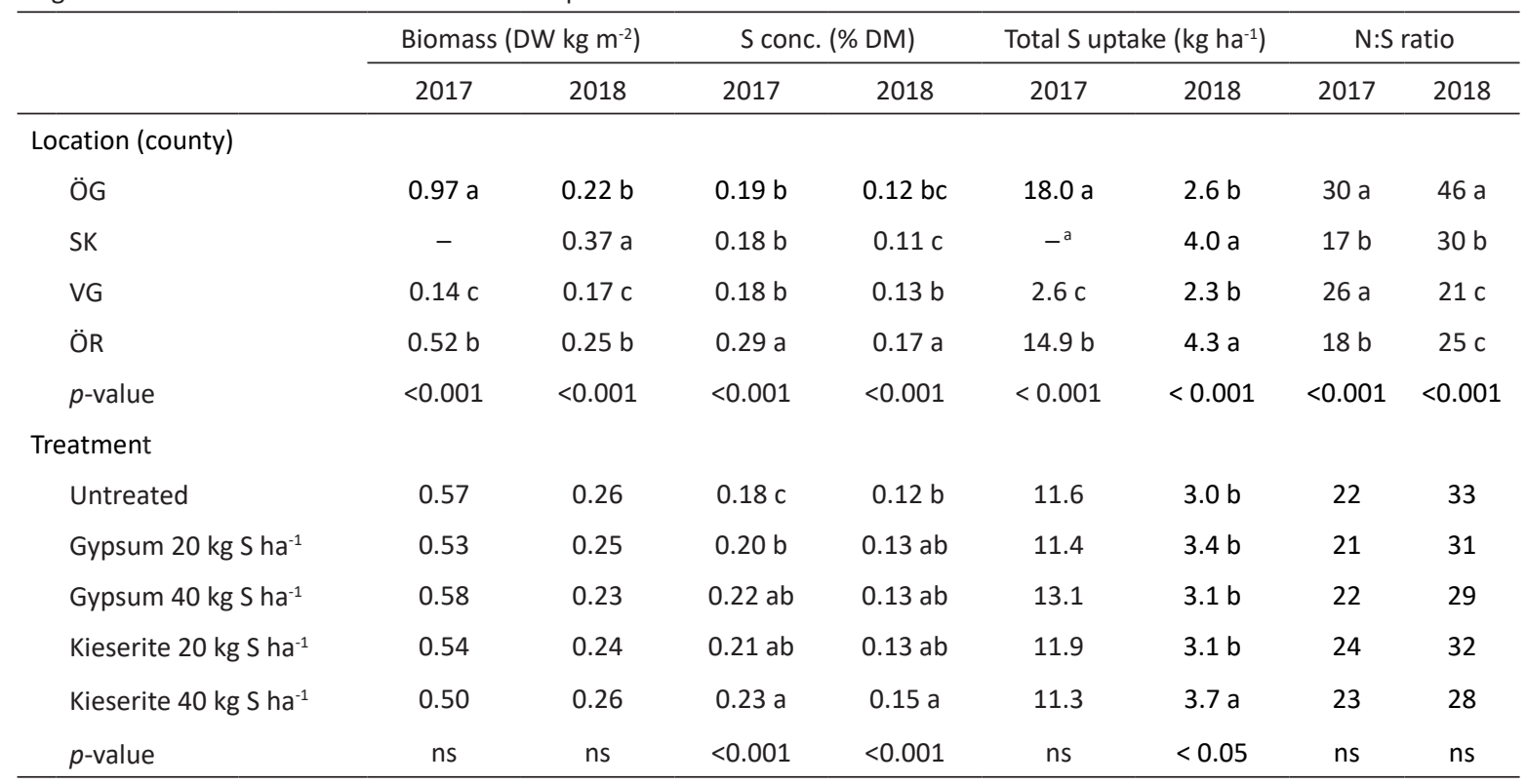

Different letters indicate significant differences between means within a column for the effects of location and treatment according to Tukey's HSD test $(p<0.05) .{ }^{a}=$ not analysed; ns = not statistically significant

\section{Concentrations of macro- and micronutrients}

There were significant differences of all analysed macro- and micronutrients in faba bean at early flowering in 2017 and 2018 between locations (Tables 4 and 5). The experimental sites that showed the lowest or highest concentrations varied with the nutrient element. The average concentrations of $\mathrm{N}$ ranged from $3.3 \%$ to $5.5 \%$ in faba bean DM in 2017 and from 2.5\% to 5.3\% in 2018 (Tables 4 and 5). There were no effects of S fertilizer treatments on macronutrient- or micronutrient concentrations in any of the eight field experiments.

\section{Faba bean seed yield}

The effect of S fertilization on seed yield varied between locations in 2017 (Table 6) and 2018 (Table 7), but not between treatments. There was an interaction between location and sulphur treatment in 2017, but it was only at location SK-17 where there was a significant difference between treatments within the field. In general, the seed yield of 2017 was highest in ÖG, followed by SK, VG and ÖR (Table 6). In 2018, the yield was highest at SK followed by ÖG and ÖR, when averaged over S treatments (Table 7). No significant differences were found between the $\mathrm{S}$ fertilization treatments and the untreated control in 2018. 
Table 4. Concentrations of macro- and micronutrients in faba bean at the beginning of flowering (BBCH 60$)$ at the four field trial locations in 2017 with various sulphur treatments

\begin{tabular}{|c|c|c|c|c|c|c|c|c|c|c|c|}
\hline & N & $P$ & K & $\mathrm{Ca}$ & $\mathrm{Mg}$ & $\mathrm{Mn}$ & B & $\mathrm{Cu}$ & Mo & $\mathrm{Fe}$ & $\mathrm{Zn}$ \\
\hline & \multicolumn{5}{|c|}{$\left(\% \mathrm{DM}^{1}\right)$} & \multicolumn{6}{|c|}{$\left(\mathrm{mg} \mathrm{kg}^{-1} \mathrm{DM}\right)$} \\
\hline \multicolumn{12}{|l|}{ Location (county) } \\
\hline ÖG-17 & $5.52 \mathrm{a}$ & $0.61 a$ & $2.24 b$ & $0.96 c$ & $0.26 \mathrm{~d}$ & $23.4 \mathrm{~d}$ & $30.8 a$ & $16.3 b$ & $1.30 \mathrm{~b}$ & $142 b$ & $42.6 \mathrm{c}$ \\
\hline SK-17 & $3.32 \mathrm{~d}$ & $0.28 c$ & $1.40 \mathrm{c}$ & $1.58 \mathrm{a}$ & $0.34 c$ & $57.0 a$ & $29.9 a$ & $10.2 \mathrm{c}$ & $0.48 c$ & $471 a$ & $55.9 b$ \\
\hline VG-17 & $4.56 c$ & $0.33 c$ & $2.40 \mathrm{~b}$ & $1.10 \mathrm{c}$ & $0.44 b$ & $30.8 c$ & $22.6 b$ & $10.4 \mathrm{c}$ & $1.41 \mathrm{~b}$ & $262 a$ & $24.1 d$ \\
\hline ÖR-17 & $5.00 \mathrm{~b}$ & $0.41 b$ & $3.08 a$ & $1.36 \mathrm{~b}$ & $0.53 a$ & $49.6 b$ & $31.2 \mathrm{a}$ & $21.3 a$ & $1.76 a$ & $368 a$ & $64.1 \mathrm{a}$ \\
\hline$p$-value & $<0.001$ & $<0.001$ & $<0.001$ & $<0.001$ & $<0.001$ & $<0.001$ & $<0.001$ & $<0.001$ & $<0.001$ & $<0.002$ & $<0.001$ \\
\hline \multicolumn{12}{|l|}{ Treatment } \\
\hline Untreated & 4.59 & 0.41 & 2.27 & 1.23 & 0.39 & 41.4 & 28.7 & 14.1 & 1.34 & 308 & 46.0 \\
\hline Gypsum 20 kg S ha-1 & 4.58 & 0.41 & 2.22 & 1.28 & 0.41 & 40.5 & 29.0 & 15.2 & 1.30 & 342 & 47.3 \\
\hline Gypsum 40 kg S ha-1 & 4.61 & 0.40 & 2.15 & 1.28 & 0.40 & 41.1 & 28.7 & 14.4 & 1.15 & 291 & 47.3 \\
\hline Kieserite $20 \mathrm{~kg} \mathrm{~S} \mathrm{ha}^{-1}$ & 4.61 & 0.41 & 2.31 & 1.25 & 0.39 & 38.7 & 28.3 & 14.1 & 1.19 & 296 & 46.9 \\
\hline Kieserite $40 \mathrm{~kg} \mathrm{~S} \mathrm{ha}^{-1}$ & 4.62 & 0.41 & 2.44 & 1.21 & 0.39 & 39.4 & 28.5 & 15.0 & 1.20 & 316 & 46.1 \\
\hline$p$-value & ns & ns & ns & ns & ns & ns & ns & ns & ns & ns & ns \\
\hline
\end{tabular}

Table 5. Concentrations of macronutrients and micronutrients in faba bean at the beginning of flowering (BBCH 60$)$ at the four field experiment locations in 2018 with various sulphur treatments

\begin{tabular}{|c|c|c|c|c|c|c|c|c|c|c|c|}
\hline & $\mathrm{N}$ & $\mathrm{P}$ & $\mathrm{K}$ & $\mathrm{Ca}$ & $\mathrm{Mg}$ & $\mathrm{Mn}$ & $\mathrm{B}$ & $\mathrm{Cu}$ & Mo & $\mathrm{Fe}$ & $\mathrm{Zn}$ \\
\hline & \multicolumn{5}{|c|}{$\left(\% \mathrm{DM}^{1}\right)$} & \multicolumn{6}{|c|}{$\left(\mathrm{mg} \mathrm{kg}^{-1} \mathrm{DM}\right)$} \\
\hline \multicolumn{12}{|l|}{ Location (county) } \\
\hline ÖG-18 & $5.33 a$ & $0.36 a$ & $2.04 b$ & $0.82 \mathrm{c}$ & $0.26 b$ & $65.6 a b$ & $21.9 b c$ & $14.8 \mathrm{a}$ & $0.26 c$ & $182 \mathrm{c}$ & $53.6 b$ \\
\hline SK-18 & $3.21 \mathrm{c}$ & $0.36 a$ & $2.43 a$ & $1.49 a$ & $0.20 \mathrm{~d}$ & $65.9 a$ & $26.1 \mathrm{a}$ & $8.3 b$ & $0.98 a$ & $255 b$ & $45.7 c$ \\
\hline VG-18 & $2.50 \mathrm{~d}$ & $0.25 b$ & $2.27 a$ & $1.09 \mathrm{~b}$ & $0.23 c$ & $55.1 b$ & $20.3 c$ & $9.1 b$ & $0.81 b$ & $167 c$ & $42.5 \mathrm{c}$ \\
\hline ÖR-18 & $4.13 b$ & $0.36 a$ & $1.95 b$ & $1.09 b$ & $0.46 a$ & $61.8 \mathrm{ab}$ & $22.6 b$ & $15.7 a$ & $0.29 c$ & $366 a$ & $69.7 a$ \\
\hline$p$-value & $<0.001$ & $<0.001$ & $<0.001$ & $<0.001$ & $<0.001$ & $<0.001$ & $<0.001$ & $<0.001$ & $<0.001$ & 0.002 & $<0.001$ \\
\hline \multicolumn{12}{|l|}{ Treatment } \\
\hline Untreated & 3.80 & 0.34 & 2.2 & 1.17 & $0.29 a b$ & 63 & 23 & 12.1 & 0.62 & 238 & 54 \\
\hline Gypsum 20 kg S ha-1 & 3.80 & 0.32 & 2.1 & 1.09 & $0.28 b$ & 60 & 22 & 11.6 & 0.61 & 241 & 50 \\
\hline Gypsum 40 kg S ha-1 & 3.68 & 0.32 & 2.1 & 1.12 & $0.28 b$ & 61 & 23 & 11.7 & 0.51 & 239 & 52 \\
\hline Kieserite $20 \mathrm{~kg} \mathrm{~S} \mathrm{ha}^{-1}$ & 3.87 & 0.33 & 2.2 & 1.11 & $0.28 a b$ & 63 & 23 & 11.9 & 0.53 & 243 & 52 \\
\hline Kieserite $40 \mathrm{~kg} \mathrm{~S} \mathrm{ha-1}$ & 3.83 & 0.35 & 2.2 & 1.12 & $0.30 a$ & 64 & 23 & 12.6 & 0.64 & 252 & 56 \\
\hline$p$-value & ns & ns & ns & ns & $<0.001$ & & ns & ns & ns & ns & ns \\
\hline
\end{tabular}

\section{Crude protein and amino acids}

The CP content of the faba bean seed was similar among the $\mathrm{S}$ treatments in 2017 but tended to differ between the $S$ treatments in 2018 (Tables 6 and 7). However, there were differences in the seed CP content between locations, where SK had the highest CP content, followed VG and ÖR, and ÖG had the lowest CP content in 2017 ( $p<$ 0.001; Table 6). In 2018, the seed CP content was highest in ÖG and ÖR, followed by VG and SK $(p<0.001$; Table 7). The protein yield of the seeds also was affected by location in both years. In 2017, the CP yield of the seeds ranked as ÖG > SK > ÖR > VG and as SK > ÖG > ÖR in 2018 (Tables 6 and 7). 
Table 6. Content of crude protein; protein yield and dry matter content (DM) of faba bean supplied with various sulphur fertilizer applications in 2017

\begin{tabular}{|c|c|c|c|c|}
\hline Main effect and interaction & $\begin{array}{l}\text { Yield } 15 \% \mathrm{WC}^{1} \\
\quad\left(\mathrm{~kg} \mathrm{ha}^{-1}\right)\end{array}$ & $\begin{array}{c}\text { Crude Protein } \\
\text { (\% of DM) }\end{array}$ & $\begin{array}{c}\text { Protein yield } \\
\left(\mathrm{kg} \mathrm{ha}^{-1}\right)\end{array}$ & $\begin{array}{c}\text { DM bean } \\
(\%)\end{array}$ \\
\hline \multicolumn{5}{|l|}{ Location (county) } \\
\hline ÖG-17 & $5531 a$ & $30.7 c$ & $1697 a$ & $70.9 d$ \\
\hline SK-17 & $4451 b$ & $33.0 \mathrm{a}$ & $1467 b$ & $85.9 b$ \\
\hline VG-17 & $3943 c$ & $31.1 \mathrm{bc}$ & $957 d$ & $75.4 c$ \\
\hline ÖR-17 & $3080 d$ & $31.9 b$ & $1256 c$ & $87.5 a$ \\
\hline$p$-value & 0.001 & $<0.001$ & $<0.001$ & $<0.001$ \\
\hline \multicolumn{5}{|l|}{ Treatment } \\
\hline Untreated & 4333 & 31.5 & 1365 & 80.0 \\
\hline Gypsum 20 kg S ha-1 & 4308 & 31.6 & 1358 & 79.9 \\
\hline Gypsum 40 kg S ha-1 & 4227 & 31.7 & 1339 & 79.9 \\
\hline Kieserite 20 kg S ha-1 & 4265 & 31.7 & 1350 & 79.9 \\
\hline Kieserite 40 kg S ha ${ }^{-1}$ & 4122 & 31.8 & 1308 & 80.0 \\
\hline$p$-value & ns & ns & ns & ns \\
\hline \multicolumn{5}{|l|}{ Location $\times$ Treatment } \\
\hline \multicolumn{5}{|l|}{ ÖG-17 } \\
\hline Untreated & $5676 a$ & 31.0 & $1760 a$ & 71.1 \\
\hline Gypsum 20 kg S ha-1 & $5651 a$ & 30.5 & $1725 a b$ & 70.9 \\
\hline Gypsum 40 kg S ha-1 & $5265 a b$ & 30.5 & $1605 a b c$ & 71.0 \\
\hline Kieserite $20 \mathrm{~kg} \mathrm{~S} \mathrm{ha-1}$ & $5795 a$ & 30.7 & $1777 a$ & 70.7 \\
\hline Kieserite 40 kg S ha-1 & $5266 a b$ & 30.7 & $1615 a b c$ & 70.7 \\
\hline \multicolumn{5}{|l|}{ SK-17 } \\
\hline Untreated & $4814 \mathrm{bc}$ & 32.6 & 1567abcd & 85.8 \\
\hline Gypsum 20 kg S ha-1 & $4490 \mathrm{bcd}$ & 33.1 & $1484 \mathrm{bcde}$ & 85.8 \\
\hline Gypsum 40 kg S ha-1 & $4480 \mathrm{bcd}$ & 33.1 & $1482 \mathrm{bcde}$ & 85.7 \\
\hline Kieserite $20 \mathrm{~kg} \mathrm{~S} \mathrm{ha-1}$ & $4404 c d$ & 33.1 & 1457cdef & 85.8 \\
\hline Kieserite $40 \mathrm{~kg} \mathrm{~S} \mathrm{ha-1}$ & $4069 d$ & 33.0 & 1344defg & 86.3 \\
\hline \multicolumn{5}{|l|}{ ÖR-17 } \\
\hline Untreated & 3130 ef & 30.5 & $955 \mathrm{~h}$ & 75.5 \\
\hline Gypsum 20 kg S ha-1 & $3090 \mathrm{ef}$ & 30.9 & $954 \mathrm{~h}$ & 75.4 \\
\hline Gypsum 40 kg S ha-1 & $3088 \mathrm{ef}$ & 31.3 & $967 \mathrm{~h}$ & 75.3 \\
\hline Kieserite $20 \mathrm{~kg} \mathrm{~S} \mathrm{ha-1}$ & $3015 f$ & 31.2 & $941 \mathrm{~h}$ & 75.3 \\
\hline Kieserite $40 \mathrm{~kg} \mathrm{~S} \mathrm{ha-1}$ & $3074 \mathrm{ef}$ & 31.6 & $971 \mathrm{~h}$ & 75.6 \\
\hline \multicolumn{5}{|l|}{ VG-17 } \\
\hline Untreated & 3712def & 31.8 & 1177gh & 87.6 \\
\hline Gypsum 20 kg S ha-1 & $4001 d$ & 31.8 & 1271efg & 87.5 \\
\hline Gypsum 40 kg S ha-1 & $4076 \mathrm{~cd}$ & 32.0 & 1303efg & 87.5 \\
\hline Kieserite $20 \mathrm{~kg} \mathrm{~S} \mathrm{ha}^{-1}$ & $3845 \mathrm{~cd}$ & 31.9 & $1225 \mathrm{fg}$ & 87.6 \\
\hline Kieserite $40 \mathrm{~kg} \mathrm{~S} \mathrm{ha-1}$ & $4080 \mathrm{~cd}$ & 32.0 & 1304efg & 87.4 \\
\hline$p$-value & 0.001 & ns & $<0.001$ & ns \\
\hline CV & 4.9 & 2.0 & 5.0 & 0.4 \\
\hline
\end{tabular}

Different letters indicate significant differences between means within a column for the effects of location and interaction between location and sulphur treatment, according to Tukey's HSD test $(p<0.05) \cdot{ }^{1}=$ water content 
Table 7. Content of crude protein, protein yield and dry matter content (DM) of faba bean supplied with various sulphur applications in 2018

\begin{tabular}{|c|c|c|c|c|}
\hline Main effect and interaction & $\begin{array}{c}\text { Yield 15\% WC (kg } \\
\left.\qquad \mathrm{ha}^{-1}\right)\end{array}$ & $\begin{array}{c}\text { Crude Protein } \\
\text { (\% of DM) }\end{array}$ & $\begin{array}{l}\text { Protein yield } \\
\qquad\left(\mathrm{kg} \mathrm{ha}^{-1}\right)\end{array}$ & $\begin{array}{c}\text { DM bean } \\
(\%)\end{array}$ \\
\hline \multicolumn{5}{|l|}{ Location (county) } \\
\hline ÖG-18 & $1478 b$ & $31.5 a$ & $397 b$ & $81.3 b$ \\
\hline SK-18 & $2267 a$ & $27.5 c$ & $529 a$ & $85.7 a$ \\
\hline ÖR-18 & $850 c$ & $31.5 \mathrm{a}$ & $228 c$ & $69.7 c$ \\
\hline VG-18 & $-{ }^{a}$ & $30.0 \mathrm{~b}$ & - & $81.0 \mathrm{~b}$ \\
\hline$p$-value & $<0,001$ & $<0.001$ & $<0.001$ & $<0.001$ \\
\hline \multicolumn{5}{|l|}{ Treatment } \\
\hline Untreated & 1535 & 30.5 & 390 & 79.5 \\
\hline Gypsum 20 kg S ha-1 & 1581 & 30.3 & 400 & 78.0 \\
\hline Gypsum 40 kg S ha-1 & 1592 & 29.8 & 395 & 81.0 \\
\hline Kieserite 20 kg S ha-1 & 1519 & 29.8 & 380 & 78.8 \\
\hline Kieserite $40 \mathrm{~kg} \mathrm{~S} \mathrm{ha}^{-1}$ & 1430 & 30.2 & 360 & 79.8 \\
\hline$p$-value & ns & $(0.094)$ & ns & $(0.082)$ \\
\hline \multicolumn{5}{|l|}{ Location $\times$ Treatment } \\
\hline \multicolumn{5}{|l|}{ ÖG-18 } \\
\hline Untreated & 1531 & 31.8 & 422 & 81.2 \\
\hline Gypsum 20 kg S ha-1 & 1606 & 31.8 & 435 & 81.2 \\
\hline Gypsum 40 kg S ha-1 & 1531 & 30.8 & 402 & 81.3 \\
\hline Kieserite $20 \mathrm{~kg} \mathrm{~S} \mathrm{ha}^{-1}$ & 1501 & 31.5 & 403 & 81.3 \\
\hline Kieserite 40 kg S ha-1 & 1189 & 31.9 & 323 & 81.5 \\
\hline \multicolumn{5}{|l|}{ SK-18 } \\
\hline Untreated & 2218 & 27.7 & 520 & 86.6 \\
\hline Gypsum 20 kg S ha-1 & 2338 & 27.7 & 551 & 85.8 \\
\hline Gypsum 40 kg S ha-1 & 2304 & 27.2 & 532 & 86.0 \\
\hline Kieserite $20 \mathrm{~kg} \mathrm{~S} \mathrm{ha}^{-1}$ & 2244 & 27.4 & 522 & 85.0 \\
\hline Kieserite $40 \mathrm{~kg} \mathrm{~S} \mathrm{ha}^{-1}$ & 2230 & 27.5 & 522 & 85.0 \\
\hline \multicolumn{5}{|l|}{ ÖR-18 } \\
\hline Untreated & 826 & 32.1 & 227 & 68.7 \\
\hline Gypsum 20 kg S ha-1 & 800 & 31.3 & 214 & 67.4 \\
\hline Gypsum 40 kg S ha-1 & 1592 & 31.3 & 250 & 74.9 \\
\hline Kieserite $20 \mathrm{~kg} \mathrm{~S} \mathrm{ha}^{-1}$ & 1519 & 31.3 & 215 & 68.3 \\
\hline Kieserite $40 \mathrm{~kg} \mathrm{~S} \mathrm{ha}^{-1}$ & 1430 & 31.5 & 234 & 69.2 \\
\hline \multicolumn{5}{|l|}{ VG-18 } \\
\hline Untreated & - & 30.5 & - & 81.6 \\
\hline Gypsum 20 kg S ha-1 & - & 30.3 & - & 77.6 \\
\hline Gypsum 40 kg S ha-1 & - & 30.1 & - & 81.7 \\
\hline Kieserite $20 \mathrm{~kg} \mathrm{~S} \mathrm{ha}^{-1}$ & - & 29.0 & - & 80.7 \\
\hline Kieserite $40 \mathrm{~kg} \mathrm{~S} \mathrm{ha}^{-1}$ & - & 30.0 & - & 83.5 \\
\hline$p$-value & ns & ns & ns & ns \\
\hline $\mathrm{CV}$ & 30.7 & 4.3 & 15.1 & 4.3 \\
\hline
\end{tabular}




\section{AGRICULTURAL AND FOOD SCIENCE}

Z.S. Omer et al. (2020) 29: 471-481

The analysed amino acids showed no differences between the $\mathrm{S}$ treatments and no interactions between the $\mathrm{S}$ treatment and location were found (Table 8). However, there were differences between the locations in both years, where ÖG and ÖR had the highest concentration of methionine compared to SK and VG $(p<0.01)$. Cysteine concentration was higher in ÖG than in SK and ÖR in $2017(p<0.01)$, whereas no differences in cysteine concentration between the locations could be found in 2018.

Table 8. Concentration of amino acids ( $\left.\mathrm{g} \mathrm{kg}^{-1} \mathrm{DM}\right)$ in faba bean treated with different products and various levels of sulphur applications at three field trial sites in 2017 and four field trial sites in 2018

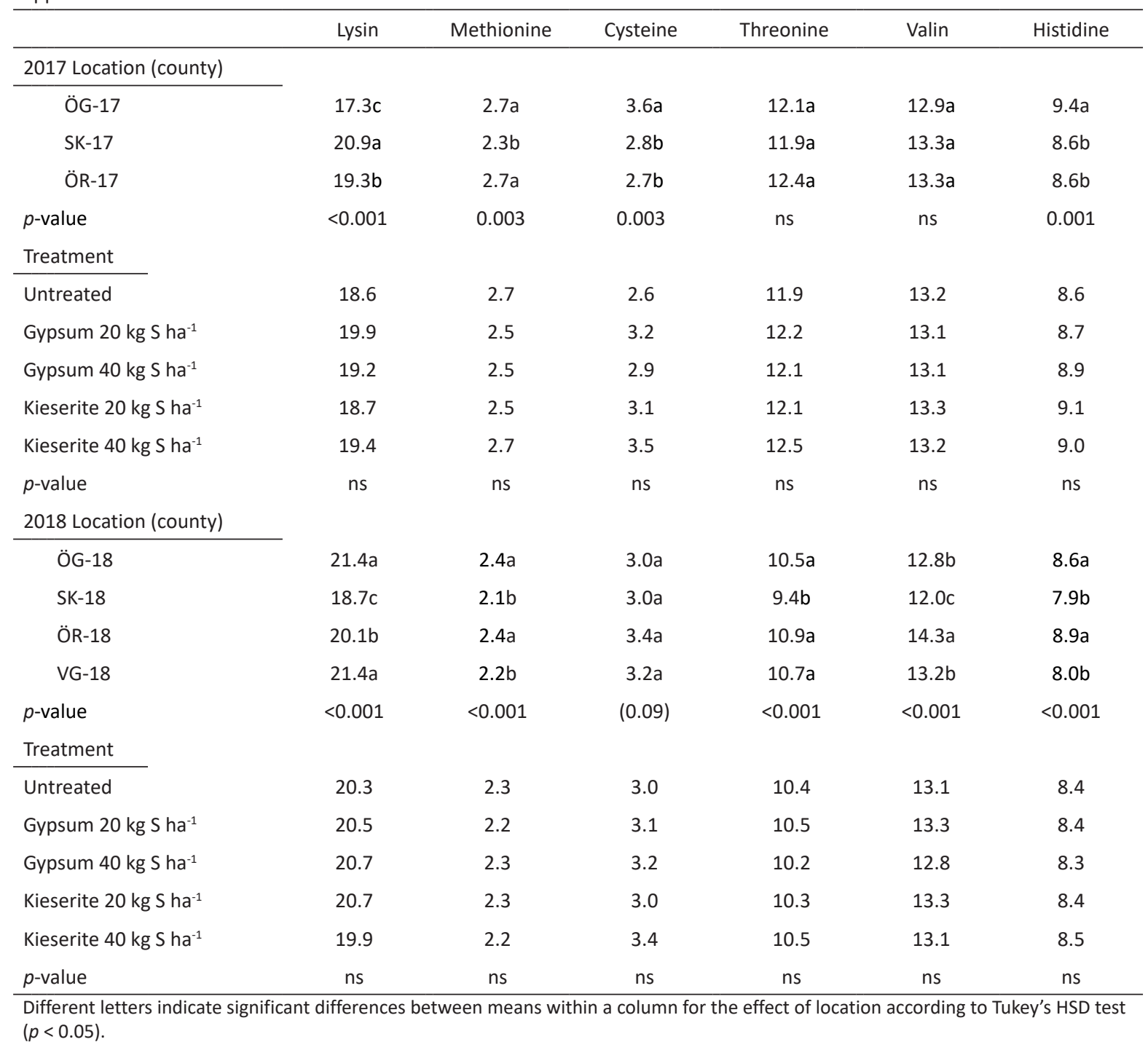

\section{Discussion}

In this study, the influence of $\mathrm{S}$ fertilization on growth, yield and quality in terms of CP and amino acid content was investigated in organically produced faba bean for the first time under field conditions in Sweden. Sulphur fertilizer treatments increased both $\mathrm{S}$ concentration and $\mathrm{S}$ uptake in faba bean dry matter. However, our results were not in accordance with hypothesis 1, i.e., that the $S$ fertilizers application in faba bean results in increased growth and yield. In general, $\mathrm{S}$ fertilization had no significant positive impact on the crop canopy density, except at the site VG-17. The $S$ content in the topsoil $(0-30 \mathrm{~cm})$ at VG-17 $\left(3 \mathrm{mg} \mathrm{kg}^{-1}\right)$ was at the same level, as experimental sites SK-17 and ÖR-17 (4 and $3 \mathrm{mg} \mathrm{kg}^{-1}$ respectively). In addition, the S-content in the biomass at VG-17 (0.18\% DM) was comparable with the respective level at ÖG-17 and SK-17 (0.19 and 0.18\% DM) respectively. Therefore, the positive effect in terms of canopy density observed in sulphur treatments as compared to control, is barely due to the reduced growth in the untreated control at this specific field experiment (VG-17), which in turn could probably be due to other factors such as weeds. In addition, there was no link between S concentration and plant dry mass weights. For example, in 2017, the dry mass weight was highest at ÖG, while S concentration was similar to that in faba bean grown at sites SK-17 and VG-17. The obtained average yield over the four field trials in 2017 was $4251 \mathrm{~kg} \mathrm{ha}^{-1}$ and for such average seed yield the average $S$ uptake was only $11.8 \mathrm{~kg} \mathrm{ha}^{-1}$ (Tables 3 and 6). 


\section{AGRICULTURAL AND FOOD SCIENCE}

Z.S. Omer et al. (2020) 29: 471-481

These results correspond with the levels reported by Pötzsch et al. (2018) where the average seed yield was 3000 $\mathrm{kg} \mathrm{ha}^{-1}$ and the average $\mathrm{S}$ accumulation in the shoots was $10 \mathrm{~kg} \mathrm{ha}^{-1}$.

The growing season of 2018 was affected by drought and heat stress, which resulted in low yields in several springsown crops. Furthermore, during 2018, the dry weight was highest in SK-18, while the S concentration in DM was significantly lower compared to the other sites. Statistical analysis did not show positive correlations between $\mathrm{S}$ in DM or seed yield. On the other hand, significant amounts of S might be mobilized to faba bean seeds, something that was not investigated in this study.

The CP content (\%) and protein yield $\left(\mathrm{kg} \mathrm{ha}^{-1}\right)$ were not affected by $\mathrm{S}$ fertilizer treatments. Thus, the results were not in accordance with hypothesis 2 , i.e., that protein content would increase, and the amino acid composition would be altered by $\mathrm{S}$ fertilizer application. Differences between the experimental sites concerning the effect of the $\mathrm{S}$ fertilizers on protein yield indicate effects of other factors, such as soil properties and the prevailing environmental conditions (Pötzsch et al. 2018). The clear differences during both years between the experimental sites in macro- and micronutrient content in DM, protein content and protein yield, indicate the complexity of the effect of $\mathrm{S}$ fertilization on faba bean and the difficulty to generate guidelines for $\mathrm{S}$ fertilization to farmers, which was also discussed by Boye (2011).

Sufficient plant-available sulphur is also important for the sulphur-containing amino acids cysteine and methionine, which are normally found at lower concentrations than most other amino acids in faba bean (Barlóg et al. 2019). The low contents of cysteine and methionine compared to other amino acids (lysine, threonine, valine and histidine) were confirmed in the present study. Gypsum and kieserite treatments did not affect the contents of cysteine and methionine, nor the other amino acids. On the other hand, there were significant differences between the experimental sites in the content of methionine, cysteine and other amino acids, which may be due to differences in weather and soil properties and mineral contents. Similar to our results, Barlóg et al. (2019) showed no effect of applying $50 \mathrm{~kg} \mathrm{~S} \mathrm{ha}^{-1}$ before sowing on the content of cysteine and methionine in faba bean. The authors explain that the soil contained sufficient amounts of $\mathrm{S}$ for the amino acid synthesis $\left(8 \mathrm{mg} \mathrm{kg}^{-1}\right)$. However, Glowacka et al. (2019) reported an increase of cysteine and methionine in common beans fertilized with $50 \mathrm{~kg} \mathrm{~S}$ per ha-1 kieserite in sulphur-poor soils in southeast Poland.

Faba bean is generally sensitive to drought and the yield can be reduced by $52 \%$ under water stress conditions (Raderschall et al. 2021). Therefore, both growth and yield were lower in the 2018 field experiments compared to 2017. The field experiment in site SK-18 had the highest yield in 2018, possibly thanks to the late rain showers $(10.6 \mathrm{~mm})$ in July, which also prolonged the growing season. Significant differences in yield levels between years and experimental sites was reported by Pötzsch et al. (2018). It is also interesting to mention that the experimental site at ÖR had the highest S concentration in faba bean DM both experimental years, but the seed yields were significantly lower compared to the other field experimental sites. The DM content of the seeds and protein yield were also lowest at ÖR, while nitrogen uptake in the biomass showed normal levels. This site had more rainfall in total during 2017 compared to the site at ÖG (303 mm vs. $188 \mathrm{~mm}$ ) and in 2018, the location at ÖR had the highest amount of rainfall in May and August, but the weather was very dry in July, hence the drought stress leading to decreased seed yield. In addition to total rainfall at each site, the amount of rainfall during the period of MayJune is suggested to play a significant role since $S$ content in dry matter and seed yield may negatively correlate with precipitation during the first 60 days (Pötzsch et al. 2018). One explanation for this might be that the vegetative growth increases in response to available water, which results in higher green biomass but eventually reduced seed yield (De Costa et al. 1997). In line with this, it can be speculated that one of several possible explanations for the highest seed yield in ÖG-17, was the lowest precipitation level during May to June (59 $\mathrm{mm}$ ) compared to other experimental sites, which had an average rainfall of $94 \mathrm{~mm}$. These differences between sites emphasize the importance of site characteristics over $\mathrm{S}$ fertilization treatments.

\section{Conclusions}

The results indicate that faba bean grown under the present conditions had no demand for sulphur fertilization. The experimental sites differed significantly in all tested parameters and therefore it can be concluded that the characteristics of a specific site plays a more significant role in faba bean growth and yield than sulphur fertilization. 


\section{Acknowledgment}

This research was funded by the Swedish Board of Agriculture (Jordbruksverket). The authors also thank Per Ståhl, Rural Economy and Agricultural Society, Östergötland, for his valuable comments.

\section{References}

Amanuel, G., Kühne, R.F., Tanner, D.G. \& Vleg, P.L.G. 2000. Biological nitrogen fixation in faba bean (Vicia faba L.) in the Ethiopian highlands as affected by P fertilization and inoculation. Biology and Fertility of Soils 32: 353-359. https://doi.org/10.1007/s003740000258

Andersson, M. 1996. Svaveltillståndet i gräsdominerande slåttervallar och möjligheter att avslöja svavelbrist. Examensarbete, Sveriges lantbruksuniversitet. (in Swedish). http://www.vaxteko.nu/html/sll/slu/ex_arb_vaxtnaringslara/EVN097/EVN097. Accessed 18 October 2015.

Barłóg, P., Grzebisz, W. \& Łukowiak, R. 2019. The Effect of Potassium and Sulfur Fertilization on Seed Quality of Faba Bean (Vicia faba L.). Agronomy 9: 209-226. https://doi.org/10.3390/agronomy9040209

Bergmann, W. 1992. Nutritional disorders of plants: development, visual and analytical diagnosis. Fisher, Jena, Germany. 742 p.

Blair, G.J., Chinoim, N., Lefroy, R.D.B., Anderson, G.C. \& Crocker, G.J. 1991. A soil sulfur test for pastures and crops. Australian Journal of Soil Research 29: 619-626. https://doi.org/10.1071/SR9910619

Boye, K., Nilsson, S.I. \& Eriksen, J. 2009. Net sulfur mineralization potential in Swedish arable soils in relation to long-term treatment history and soil properties. Biology and Fertility of Soils 457: 743-751. https://doi.org/10.1007/s00374-009-0390-y

Boye, K. 2011. Sulfur cycling in Swedish arable soils, a chemical perspective. Doctoral thesis, Swedish University of Agricultural Sciences, Uppsala, Sweden. ISSN 1652-6880.

Cazzato, E., Tufarelli, V., Ceci, E., Stellacci, AM. \& Laudadio, V. 2012. Quality, yield, and nitrogen fixation of faba bean seed as affected by sulphur fertilization. Acta Agriculturae Scandinavica. Section B - Soil and Plant Science 62: 732-738. https://doi.org/10.1080/09064710.2012.698642

De Costa, W.A.J.M., Dennett, M.D., Ratnaweera, U. \& Nyalemegbe, K. 1997. Effects of different water regimes on field-grown determinate and indeterminate faba bean (Vicia faba L.). II. Yield, yield components and harvest index. Field Crop Research 52: 169-178. https://doi.org/10.1016/S0378-4290(96)01060-X

Eppendorfer, H.W. \& Eggum, B.O. 1996. Fertilizer effects on yield mineral and amino acid composition, dietary fibre content and nutritive value of leeks. Plant Foods for Human Nutrition 49: 163-174. https://doi.org/10.1007/BF01091974

Eriksen, J. \& Mortensen, J.V. 1999. Soil sulphur status following long-term annual application of animal manure and mineral fertilizers. Biology and Fertility of Soils 28: 416-421. https://doi.org/10.1007/s003740050514

Jonsson, P. 2012. Svavel i vallar. Arvensis 6: 22-23. (in Swedish).

Jordbruksverket 2019. Rekommendationer för gödsling och kalkning. (in Swedish).

Josefsson, E. 1970. Glucosinolate content and amino acid composition of rapseed (Brassica napus) meal as affected by sulphur and nitrogen nutrition. Journal of the Science of Food and Agriculture 21: 98-103.https://doi.org/10.1002/jsfa.2740210211

Glowacka, A., Gruszecki, T., Szostak, B. \& Michalek, S. 2019. The response of common bean to sulphur and molybdenum fertilization. International Journal of Agronomy 2019: Article ID 3830712. 8 p. https://doi.org/10.1155/2019/3830712

Klein, H., Gauss, M., Nyiri, A. \& Stensen, B.M. 2011. Transbounding air pollution by main pollutants (S, N, O3) and PM. Norwegian Meteorological Institute, Data note 2011, ISSN-1890-0003.

Marschner, H. 1995. Mineral Nutrition of Higher plants. Academic Press, California, USA. p. 889.

Pedersen, C.A., Knudsen, L. \& Schnug, E. 1998. Sulfur fertilization. In: Schnug, E. (ed.). Sulfur in agroecosystems. Dordrecht: Kluwer Academic Publishers. p. 115-134. https://doi.org/10.1007/978-94-011-5100-9_4

Pihl-Karlsson, G., Karlsson, P.-E., Akselsson, G., Kronnäs, V. \& Hellsten, S. 2013. Krondroppsnätets övervakning av luftföroreningar i Sverige- mätningar och modellering. IVL rapport B2095. (in Swedish).

Pötzsch, F., Lux, G. \& Schmidtke, K. 2018. Sulphur demand, uptake and fertilization of Vicia faba L. under field conditions. Field Crop Research 228: 76-83. https://doi.org/10.1016/j.fcr.2018.08.013

Scherer, H.W. 2001. Sulphur in crop production - invited paper. European Journal of Agronomy 14: 81-111. https://doi.org/10.1016/S1161-0301(00)00082-4

Scherer, H.W. 2009. Sulfur in soils. Journal of Plant Nutrition and Soil Science 172: 326-335. https://doi.org/10.1002/jpln.200900037

Raderschall, C.A., Vico, G., Lundin, O., Taylor, A.R. \& Bommarco, R. 2021. Water stress and insect herbivory interactively reduce ith automatic milking systems. Journal of Dairy Science 85: 2869-2878. https://doi.org/10.3168/jds.S0022-0302(02)74374-9

Tallec, T., Diquélou, S., Fauveau, C., Bataillé, M.P. \& Ourry, A. 2008a. Effects of nitrogen and sulphur gradients on plant competition, $\mathrm{N}$ and $\mathrm{S}$ use efficiencies and species abundance in a grassland plant mixture. Plant and Soil 313: 267-282. https://doi.org/10.1007/s11104-008-9699-9

Tallec, T., Diquélou, S., Lemauviel, S., Cliquet, J.B., Lesuffleur, F. \& Ourry, A. 2008b. Nitrogen: sulphur ration alters competition between Trifolium repens and Lolium perenne under cutting: Production and competitive abilities. European Journal of Agronomy 29: 94-101. https://doi.org/10.1016/j.eja.2008.04.004

Weber, E. \& Bleiholder, H. 1990. Erläuterungen zu den BBCH-Dezimal-Codes für die Entwicklungsstadien von Mais, Raps, FabaBohne, Sonnenblume und Erbse -mit Abbildungen. Gesunde Pflanzen 42: 308-321. (in German). 